Article

\title{
Impact of Strategic Orientations on the Implementation of Green Supply Chain Management Practices and Sustainable Firm Performance
}

\author{
Md. Ahashan Habib ${ }^{1, *(D)}$, Yukun Bao ${ }^{2}\left(\mathbb{D}\right.$, Nurun Nabi $^{1,3}$ (D) , Marzia Dulal ${ }^{1}$, Asma Ansary Asha ${ }^{1}$ \\ and Mazedul Islam 4 (D)
}

1 Department of Textile Engineering Management, Bangladesh University of Textiles, Tejgaon, Dhaka 1208, Bangladesh; nurunnabi74@yahoo.com (N.N.); dulalmarzia@gmail.com (M.D.); asmaansarya38@gmail.com (A.A.A.)

2 Center for Modern Information Management, School of Management, Huazhong University of Science and Technology, Wuhan 430074, China; yukunbao@hust.edu.cn

3 Department of Business administration, School of Management, Huazhong University of Science and Technology, Wuhan 430074, China

4 Department of Materials, The University of Manchester, Manchester M13 9PL, UK; mazed@butex.edu.bd

* Correspondence: ahashan.tem@butex.edu.bd; Tel.: +88-018-1384-4104

check for

updates

Citation: Habib, M.A.; Bao, Y.; Nabi, N.; Dulal, M.; Asha, A.A.; Islam, M. Impact of Strategic Orientations on the Implementation of Green Supply Chain Management Practices and Sustainable Firm Performance. Sustainability 2021, 13, 340. https://doi.org/10.3390/su13010340

Received: 14 November 2020 Accepted: 11 December 2020 Published: 1 January 2021

Publisher's Note: MDPI stays neutral with regard to jurisdictional clai$\mathrm{ms}$ in published maps and institutional affiliations.

Copyright: (C) 2021 by the authors. Licensee MDPI, Basel, Switzerland. This article is an open access article distributed under the terms and conditions of the Creative Commons Attribution (CC BY) license (https:// creativecommons.org/licenses/by/ $4.0 /)$.

\begin{abstract}
Ensuring sustainability through green supply chain management practices has become challenging for the textiles and garments industry. Organizations need to examine the factors of the firm's sustainability performance and how to manage them strategically. Hence, the strategic organizational orientation can be the best approach for implementing green supply chain management (GSCM) practices to improve firm sustainability performance. This study aims to assess the impact of strategic orientation in three dimensions, such as green entrepreneurial orientation (GEO), market orientation (MO), and knowledge management orientation (KMO) on the implementation of green supply chain management (GSCM) practices and the subsequently sustainable firm performance. Data were gathered from an extensive scale survey of 266 respondents of textile manufacturing firms in Bangladesh. Data were analyzed in the structural equation model (SEM) with partial least squares techniques to justify the proposed hypotheses. The results reveal that GEO and MO have a significant positive effect on GSCM practices, affecting sustainable firm performance. Surprisingly, KMO does not have a positive impact on GSCM practices. Further, this study reveals that GSCM practices partially mediate the relationship between GEO and sustainable firm performance while $\mathrm{MO}$ and KMO partially mediate the relationship between GEO and GSCM practices. Overall, findings help textiles firm management comprehensively understand the implementation strategies of GSCM practices in operations and reconfigure accordingly in the competitive business environment while improving firm performances. This study is the first to investigate the effect of strategic orientation on GSCM practices implementation in the textiles industry from the context of an upstream operation with a comprehensive understanding of the factors while reducing environmental impact.
\end{abstract}

Keywords: strategic orientation; green supply chain management; environmental performance; knowledge management; textile and garments industry

\section{Introduction}

The textiles and garments industry needs fundamental changes in the business models towards sustainable development, given the devastating environmental and social impact in their supply chain operations [1]. According to the World Commission on Environment and Development (WCED) report, "sustainable development means to meet the needs of the present without compromising the ability of future generations to meet their own needs" [2]. From the business perspective, the Environmental Protection Agency stated that "sustainability could be defined as the goal for long-term shareholder and social value 
creation with minimizing the negative environmental impact" [3]. Due to rising global environmental awareness, green supply chain management (GSCM) practices became essential and one of the most effective sustainability practices among the practitioners, researchers, NGOs, and industries [4]. Research notes that textiles and garments industry management are struggling to address sustainability issues in their business supply chain, given the complex nature of operations [5].

Strategic orientation is a well renowned and broader area in business management literature. The firm strategic activities can describe the general meaning of strategic direction, which directly influences to accomplish superior firms performance [6]. Over the years, researchers have identified different strategic orientation types indicating their multidimensional implications at the organization level. Our study has chosen green entrepreneurial, market, and knowledge management orientation, which are correlated and have the highest influential capability to adopt organizational environmental activities and contribute to superior firm performance $[7,8]$.

First, this study demonstrates the association between green entrepreneurial orientation and GSCM practices from the dynamic capability view. Second, we have shown the association between MO and GSCM practices from the resource advantages theory. Third, the resource-based view theory is applied to address the relationships between KMO and GSCM practices in this study. Fourth, this study addresses the GSCM practices and sustainability performance relationship from a natural resource-based perspective. Though sustainability performance encompasses economic, environmental, and social understanding, our study excludes social performance due to much research exists on the social performance dimension.

Prior studies have examined the relationship between strategic orientation and business performance [4,9]. On the other hand, many studies found the implementation of GSCM practices contributes to firm sustainability performance [10,11]. However, little research is assessing the strategic orientation and GSCM practices regarding organizational economic and environmental performance. However, an overall strategic orientation perspective on implementing green supply chain management best practices concerning sustainability performance lacks theoretical and practical literature. Moreover, prior research of GSCM course was either simple direct effect analysis [12] or institutional pressure antecedent-based $[13,14]$ or identify the components and their importance [15]. However, this study is the first attempt to identify the firm-level ancestors of GSCM in the form of strategic orientation.

Until recently, much research has proven the link between strategic orientation and firm performance $[16,17]$, but there is little specific direction on how SO brings the performance [18]. For example, most recently, [17] identified SO's proactive activities positively influencing firm economic and environmental performance. To our knowledge, there are limited studies that have systematically investigated the strategic ways of achieving superior firm performance while ensuring sustainability, particularly in terms of the textiles manufacturing business. Therefore, a lack of research exists between SO and firm performance. Meanwhile, researchers argue the need to explore the practical process of $\mathrm{SO}$ and firm performance rather than the direct effect [18]. Hence, our study explores the influential factors of SO, such as adopting GSCM practices, which bring superior sustainable firm performance [19]. In addition, we examine how MO and KMO mediate between GEO and GSCM practices. This research aims to fill-up those gaps and explores new dimensions of how firms can meet the green needs of their stakeholders, as well as improving sustainability performance.

Having a substantial negative impact, sustainable growth of the textile industry is a great challenge given the forcibly global trade environment, and the manufacturers are struggling to implement GSCM practices and improve firm performances [20,21]. The study concentrates on the Bangladeshi textile and garments industry, strategically an essential sector from socioeconomic contexts. Bangladeshi textiles industry presents an ideal case scenario of empirical research since it has been positioned as the second-largest 
textile and garment product exporter globally 5.1\% market share [22], a critical global supplier, and an emerging developing economy in South Asia [23]. Export earnings of Bangladesh have come $84 \%$ from textile and RMG sector where $82 \%$ are women workers and provide 4.4 million jobs and contribute 13\% of national GDP [23]. The massive growth of the textile sector has contributed to the national economy, but sustainability issues have been worst, experiencing water, air pollution, workplace safety, and worker social security problems. Finally, after two recent incidents at the Tazreen fashion fire result of 112 people died. The Rana Plaza collapse results in 1129 people failed and injured of 2000 peoples [22], have awakened the government, customer, trade union and all others stakeholder to improve the workplace safety, worker safety, environmental and social sustainability [24,25]. Though Bangladesh Accord (formed by the 190 European-based buyers with 1700 suppliers) and Alliance (formed by 26 US-based clothing brands with 700 suppliers) have been developed to improve and maintain the workplace safety and worker safety issues, there is less attention on environmental issues [22]. This crisis has negatively affected many industries in this sector, hence the need to reexamine existing practices to improve present capabilities or modification [26]. In this momentum, the textile industries of Bangladesh have realized the importance of GSCM practices for the triple bottom line of sustainability success. However, until recently, its adoption is still in infancy [27]. However, it is not easy to practice GSCM without motivation, pressure, top management support, green infrastructure, green supply, and green information system facility [28-30]. Government pressure, organizational culture, green knowledge, technological and financial capability, economic and social benefits from green practices may be the backdrop for GSCM adoption in the Bangladeshi textile industry [31]. Moreover, some enterprises have adopted ISO9000, ISO14001, LEED, BSCI, WRAP, OEKO-TEX, SEDEX certification, but still, many industries are lagging behind GSCM practice $[27,32]$. Hence, organizations are needed to be strategic in adopting GSCM practices to improve sustainability performance.

In general, the main objectives of this research are to examine the effect of entrepreneurial orientation, market orientation, and knowledge management orientation as a strategic orientation on implementation of green supply chain management practices and subsequently measure the sustainability performance of the textile manufacturing industry in Bangladesh.

Driven by crucial literature analysis, this research aims to answer the following questions:

(1) How does the strategic orientation of an organization influences the adaptation and implementation of GSCM practices on textile manufacturing firms?

(2) How do GSCM practices impact the sustainability performance of textile manufacturing firms?

(3) How do GSCM practices mediate between GEO and sustainability performance?

(4) How do GSCM practices and GEOs mediate from knowledge management orientation and market orientation contexts?

This research has some significant contributions to theory and practice. First, our study illustrates the current GSCM literature while identifying a new antecedent of GSCM rules. Second, the mediation effect of GSCM methods leads to superior firm performance, and it has identified the intermediary link between GEO and sustainable firm performance. Third, market orientation is exerted to the eco-friendly customer expectation. Knowledge management orientation acquires internal and external knowledge of the organization, motivating the GEO firm to initiate and develop GSCM capabilities that improve sustainability performance.

The article is structured as literature insights in Section 2, and the research framework with critical hypothesis development in area 3. Section 4 describes the research methodology of the study; Section 5 presents results and analysis. Finally, Section 6 describes the discussion and implication followed by conclusions in Section 7. 


\section{Literature Review}

\subsection{Natural Resource-Based View and Green Supply Chain Management Practices}

The natural resource-based theory (NRBV) considers the constraints of the planet's natural resources [33]. Thus, SCM activities should be re-engineered to achieve business and environmental sustainability simultaneously. Hart [33] proposed three interrelated strategies: pollution prevention, sustainable development, and product stewardship. Green supply chain management (GSCM) in operation touches firms from multidimensional contexts, and it helps a firm gain strong potential for sustainable firm performances [29,34]. GSCM practices can be described as green initiatives right from design, procurement, manufacturing, delivery, up to product recovery in the essence of reducing, reuse, recycling resources (e.g., energy) to reduce the environmental impacts [35]. In the modern dynamic business environment of the textile industry, GSCM practices are considered to be an intangible strategic capability that enables business practitioners to gain a competitive advantage for their firms with improved performances [1]. There are multidimensional aspects of research on GSCM practices both in theory and practice, such as conceptualizing strategic implications of green manufacturing procedure and their implementation $[1,36]$. In this research, GSCM is defined as a dynamic capability consisting of strategies orientation, practices, and policies that includes managing the internal and internal environmental impact of supply chain operations towards superior firm performance and gaining strategic advantages [37]. In prior research, different dimensions have been found as GSCM practices such as internal environmental management, eco-design, green purchasing, customer cooperation, investment recovery, reverse logistics, supplier collaboration, and waste management as GSCM practices. However, to measure GSCM practices, following an extensive literature analysis, we have selected internal environment management, eco-design, and customer cooperation.

\subsection{Dynamic Capability View and Green Entrepreneurial Orientation}

Dynamic capabilities direct the organization's competencies in rapidly changing environments by recognizing, integrating, and developing the right decision at the right time and in the right place [38]. Dynamic capability enhances the firm's learning ability, incorporates learning firms, and restructures the substantial resources in new product and process innovation to achieve sustainable competitive advantages. It has three qualities, such as sensing capability, which identifies the unique opportunity; seizing capability, which leverages the resources to meet the potential opportunity and transforming ability, which restructures the organization always in updated form. In line with these, green innovation of products, proactive posture to avail market opportunities with a risk-taking tendency are few fundamental approaches that are embedded within GEO and help achieve sustainable goals with strategic advantages [19].

A strategic orientation, consequently, directs the businesses and finds them in identify customer needs and wants dedicatedly by introducing new products in the market before their competitors [39]. In the entrepreneurship literature, business growth and value creation depending on entrepreneurial activities to identification and exploration of business opportunities through innovation, proactive behaviors, and risk-taking decisions [39-41]. Different research has given other names to green entrepreneurship, such as ecopreneurship, environmental entrepreneurship, and sustainable entrepreneurship, which stands different meanings [42].

Many researchers focus on entrepreneurial actions to change the world instead of profit earning $[43,44]$. Some other research means that green entrepreneurs are also making a profit and findings new opportunities with their aims to green innovation, risk-bearing, and searching for new opportunities [45]. According to Dean and McMullen [42], green entrepreneurship is a propensity to identify potential opportunities that may create economic and ecological welfares by initiating green activities. Usually, entrepreneurial orientation grasps the firm decision-making posture in the critical firm-level task, strategy-making 
process, and managerial ideas to find out new opportunities for organizational growth and renewal [18].

\subsection{Resources Advantages Theory and Market Orientation}

The resource advantage theory indicates that resources are a tangible substance that can be delivered shortly and effectively to the market segment according to customer needs and demands [46]. Market orientation can define the firm's strategies and operations, which are taken to meet the present and future application of the product and market [47]. Zahra [48] advocates firms with higher market orientation, maintaining good customer relationships and establishing excellent customer value. By accurately collecting, monitoring, and analyzing the customer demand trend while investigating competitor strategy, the $\mathrm{MO}$ firms can take strategic decisions to achieve competitive advantages. Resourceadvantage theory suggests that market orientation is a rare and valuable resource of a firm to make differentiation and customer value delivery to enhance competitive advantage [47]. According to this theory, firms can achieve superior performance by accurately capturing market knowledge and making proper management decisions to convert firm indistinctive resources to the market offering, which is creating value to one or more market segments [49]. GEO firm captures market knowledge and takes strategic decision-making to translate these comparative advantages to competitive advantages through GSCM practices. GSCM practices are the organizational key differentiation of environmental practices by which organizations can achieve economic, social, and ecological performance [11]. In this globalization and open market, more than thousands of competitors are offering the product to the market. However, only the company who have a better knowledge of customer needs and wants and can satisfy their customer may get competitive advantages.

Market orientation can be defined as the ability to identify and satisfy customers' needs [50,51]. This study considered two behavioral views of market orientation as customer orientation and competitor orientation. Recently, with the growth of environmental concerns, customers are more demanding, environmentally friendly products [49]. Market orientation firms capture such needs and mobilizing firm resources towards green initiatives [17]. Since the market orientation firm has higher market knowledge than its competitors. Market-oriented firms are always systematically collected, monitor, analyze the competitor strategy, and take green action to achieve competitive advantages [49]. Market orientation enhances marketing advantages through the sustainable affiliation of GSCM practices. Market orientation is an intangible resource that improves management knowledge about customer demand for the environmental product. Market-oriented manager utilizes this demand knowledge and takes strategy to satisfy both customers and owners through GSCM practices.

\subsection{Resource-Based View and Knowledge Management Orientation}

The resource-based view (RBV) is a useful theoretical framework to understand how competitive advantage is achieved within companies and how that advantage can be maintained over time [52-54]. It has become one of the critical theoretical perspectives with widespread acceptance in strategic management [55-57]. However, traditionally, marketbased approaches focused on how external factors, opportunities and threats, or internal source strengths and weaknesses in an isolated way influenced the strategies and the performance of the company, and how these could be combined to explain how companies could prosper and achieve a competitive advantage. The resource-based view (RBV) is an appropriate logical framework to understand how competitive advantage is achieved and sustained within the companies over time [53]. Knowledge is a strategic organizational resource that guides firms to achieve competitive performance. Hence, the organization should emphasize developing their understanding of based support and collect market knowledge [58]. Learning is a strategic resource that obtains stores, shares, and applies for a better acquiring customer and competitor knowledge to develop a competitive position in the marketplace [59]. Experience is a valuable, rare, inimitable, and non-substitutable 
resource, which develops them into a more imperishable firm [60]. In the supply chain process, they need to share knowledge and information among supply chain partners to finish the different functions and meet customer demand [61].

\section{Research Framework and Hypothesis Development}

\subsection{Research Model}

Driven by the current literature study, we theoretically propose that strategic orientation has the powerful capability to adopt and implement GSCM practices in the industry. This study proposes the positive relationship between strategic orientation and sustainable firm performance is positively mediated by GSCM practices. The study also indicates that $\mathrm{MO}$ and $\mathrm{KMO}$ have a positive mediation relationship between GEO and GSCM practices. Then we theoretically developed a research model (Figure 1) and proposed ten hypotheses.

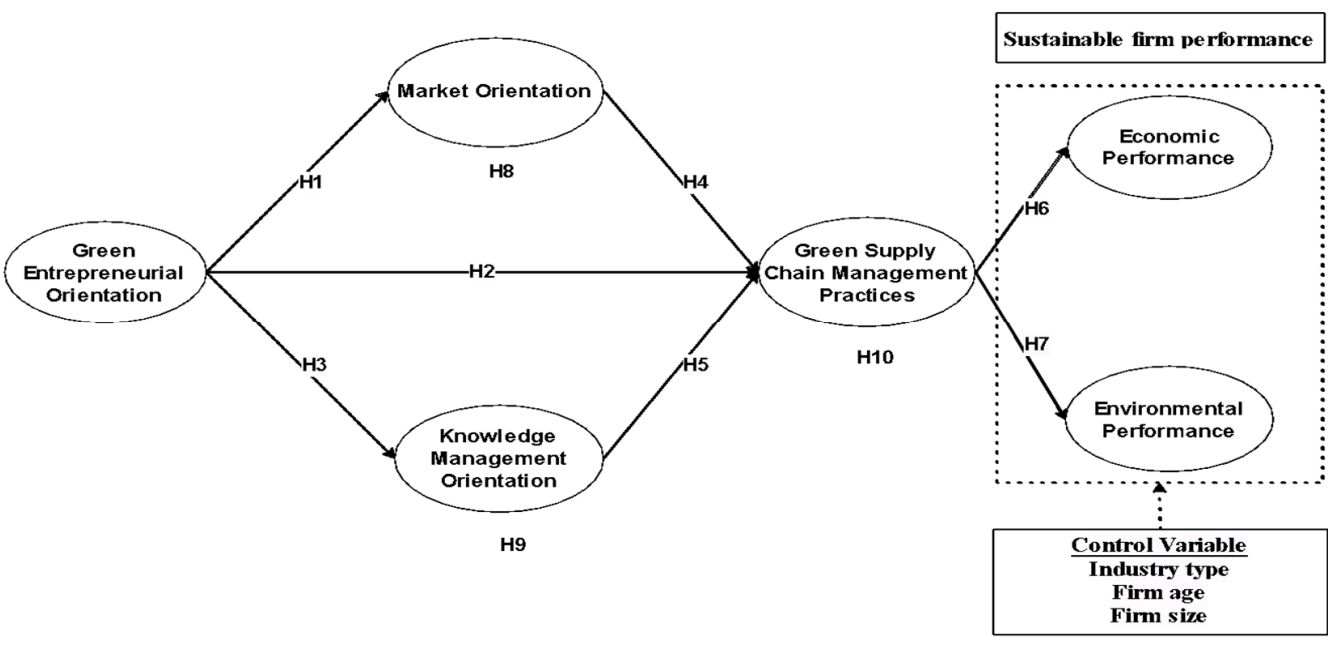

Figure 1. Conceptual research model.

\subsection{Research Hypothesis}

\subsubsection{Green Entrepreneurial Orientation and Market Orientation}

According to the dynamic capability perspective, GEO firms identify the potential market opportunity and take innovation initiative, proactive posture, and risk-taking to achieve superior performance. The previous study established a direct positive link between GEO and firm economic and environmental performance [17]. This study attempts to identify the immediate effect of GEO on MO. According to resource advantages theory, $\mathrm{MO}$ is an intangible resource by which firms can achieve superior performance through precisely management decisions to occupy specific marketplace positions over their competitors and gain a competitive advantage [47]. A market-oriented firms need to be systematically collect, monitor, and analyze the rapid change of customer needs and demands, and analyze how to market delivery impact customer satisfaction, also how product innovation influence customer demand, and take strategic marketing implementation plan to achieve competitive advantages [62]. The nexus between the relationship between GEO and $\mathrm{MO}$ is clear; the entrepreneurial strategic and tactical decision-making depends on appropriately identify the needs and demands of the customer through proper marketing practices [63]. Thus, it is proposing the hypothesis is as follows:

Hypothesis H1. Green entrepreneurial orientation has a positive influence on market orientation.

\subsubsection{Green Entrepreneurial Orientation and Green Supply Chain Management Practices}

From the dynamic capability view, GEO sensing capabilities identify the appropriate market opportunity. Usually, they take proactive action to adopt green practices to meet the present and future challenges rising from environmentally conscious customers and 
stakeholders [19]. GEO seizing capabilities encourage the firm to mobilize the resource to adopt green technologies, green manufacturing, which improves production efficiency reducing energy consumption and pollution prevention [17]. GEO transforming aptitude encourages the firm to adopt green strategies in an uncertain environment, in the essence of GEO's foresight, the market opportunity [38]. GEO firm exploits the single opportunity as green practice such as sales of excess inventories, scrap and used materials [10], harvesting the rainwater, wastewater reuse, recycle, use of energy-saving and solar light may enhance economic and environmental performance [64]. To uphold the corporate reputation, GEO firm undertakes internal ecological management practices such as ISO 14000, E.M.S., environmental compliance, and auditing programs [14]. GEO transforming capability encourages the firm to adopt green strategies in an uncertain environment. Traditional practices change to green rules in the essence of GEO's foresight of the market opportunity [65]. From the above discussion, this study posits the following hypothesis:

Hypothesis H2. Green Entrepreneurial Orientation has a positive influence on adopting green supply chain management practices.

\subsubsection{Green Entrepreneurial Orientation and Knowledge Management Orientation}

Entrepreneurs identify customer demand and innovate new products to meet market demand [66]. According to [38], dynamic organizations are continuously searching for new opportunities; thus, the organization needs market, information, and knowledge. Due to the proliferation of information technology, customer demand is frequently changing, and organizations need to identify these market changes and take a strategic orientation to meet the current application [60]. Thus, entrepreneurs are looking and acquiring the right knowledge of the market information and taking proactive steps to innovate new products and gain a competitive advantage. As a result, this study hypothesizes:

Hypothesis H3. Green Entrepreneurial Orientation has a positive influence on knowledge management orientation.

\subsubsection{Market Orientation and Green Supply Chain Management Practices}

Previous research has established the relationship between market orientation and environmental training implementation, such as GSCM practices [47,50]. With the recently growing concern of environmental issues, the customers are demanding eco-friendly products. Hence the MO firms have significantly adopted GSCM practices to meet customer demand through manufacturing their product in an environmentally sustainable manner [47]. Agarwal, Krishna Erramilli [67] stated that market orientation significantly enhances firm innovation performance. Similarly, Matear, Osborne [68] revealed that innovation positively mediates the relationship between market orientation and business performance. Hence, it is justified that MO spurs innovation in enhancing environmental contributions. A strong MO firm prioritizes the customer needs and wants, analyzing competitor strategies, and develops the firm ability, such as GSCM, to satisfy the customer [49]. According to Rehman and Shrivastava [69], customer pressure has a significant influence on adopting and implement environmentally sustainable practices. Hence, manufacturing firms are following and act proactive posture in responding to customer demands for developing ecologically sustainable processes and products through adopting and implementing green supply chain management practices [70]. The resource-advantage theory suggests that $\mathrm{MO}$ is an intangible resource that develops the strong ability to generate intelligence in the changes with customer demand and leverages the firm resource to satisfy the customer through green innovation and GSCM practices [47]. Hence, the study proposed the hypothesis is as follows:

Hypothesis H4. Market orientation has a positive influence on adopting green supply chain management practices. 


\subsubsection{Knowledge Management Orientation and Green Supply Chain Management Practices}

The organization is embedded with a different functional department that needs knowledge and information to make a strategic decision and action plan. Hence, KMO is vital to firm resources to acquire, create, transfer, share knowledge, and informationoriented tasks within the organization [71]. Generally, a prior study found two kinds of knowledge. One of the first kinds is managing technology-oriented knowledge that can be easily copied, stored, and distributed. Another type of knowledge is human capital, which is difficult to copy, store, and distribute. Hence, human capital knowledge is a unique resource of an organization [59]. Generally, any organization's GSCM practices depend on the level of expertise and importance given by the top and mid-level management of an organization. Hence, the study proposed the below hypothesis:

Hypothesis H5. KMO has a positive influence on adopting GSCM practices.

\subsubsection{Green Supply Chain Management Practices and Sustainable Firm Performance}

GSCM practices enhance economic performance by reducing the cost of purchased material, improving energy utilization, reducing the cost of waste treatment and waste discharge [29]. GSCM practices enhance environmental performance by reducing water, power, harmful and toxic chemicals during production and minimizing the waste produced in manufacturing, effluent discharge, and air pollution [11,47]. Eco-design practices improve product functionality, reduce energy consumption and waste treatment cost, and consecutively lessen lifecycle environmental effects [10]. There is a controversial issue in GSCM practices is that it does not bring economic performance directly. For example, [72] stated that the GSCM approach does not bring short rum profitability and sales performance. At the same time, [73] mentioned that green purchasing incurred more business costs, which affect negative financial performance. In the other view, GSCM practices bring positive economic performance in different ways. First, GSCM practice brings economic performance by reducing the cost of production and minimizes the energy and waste related cost. Second, GSCM practices improve the company's corporate reputation and develop loyalty for the customer for which in the long run, it brings economic performance. From the above discussion, the study posits the following hypothesis:

Hypothesis H6. GSCM practices have a positive and significant influence on economic performance.

Hypothesis H7. GSCM practices have a positive and significant influence on environmental performance.

3.2.7. The Mediation effect of Market Orientation between Green Entrepreneurial Orientation and GSCM Practices

Prior study has established the relationship between market orientation and GSCM practices [47,50], but this study investigates the mediation effect of MO between the relation of GEO and GSCM practices. The firm's orientation depends on how they align with either customer or competitor, in particular, to what extent firms are developing and introducing new products [49]. Market changes and needs often influence managerial decisions, making, and practices. The heterogeneity of firms' adoption of GSCM practices depends on the level of market orientation. Under the dynamic capability view, the GEO firms sensing capability can identify the market demand, take a proactive environmental strategy, and innovate environmentally friendly products and services [17]. GEO oriented firm is seeking customer cooperation to produce a green product. When the customer's demand for the environmentally friendly product is rising, the GEO firm acts quickly responsive to fulfill market demand in an ecologically sustainable manner such as GSCM practices to the satisfied environmental friendly customer [47]. On the other hand, organizations are embedded within competitors, and GEO firms always monitor competitor strategy. 
Systematically and continuously collecting, monitoring, and analyzing competitor strategy GEO firm take proactive environmental initiatives such as GSCM practice before their competitor action [49]. Hence, the conceptualize hypothesis of this study as follows:

Hypothesis H8. Market orientation positively mediates the relationship between GEO and GSCM practices.

3.2.8. The Mediation Effect Knowledge Management Orientation between Green Entrepreneurial Orientation and GSCM Practices

Knowledge management orientation provides the information of suppliers and customers of the organization. Tseng [74] highlighted that KMO helps the organization to keep proper communication with updated information, developing and managing good relationships with its suppliers for growing business improvement. Prior studies mention that knowledge sharing within supply chain members and cooperation with the business partners has significant benefits for firm performance [75]. Wilburn Green, Toms [47] mentioned that customer demand information and knowledge significantly influence developing a firm capability to meet the current requirement. Hence from the above discussion, we proposed the following hypothesis:

Hypothesis H9. Knowledge management orientation positively mediates the relationship between GEO and GSCM practices.

3.2.9. The Mediation Effect of Green Supply Chain Management Practices between Green Entrepreneurial Orientation and Firm Performance

Green entrepreneurial orientation has the vision to change society by reducing pollution prevention and reducing environmental impact $[16,76]$. GEO is undoubtedly the combination of some entrepreneurial characteristics as a decision-making posture towards the strategy-making process [18], which cannot directly achieve firm performance without its tactical actions such as GSCM practices. The researcher also argues that mediation linkage may need to test the best effect between GEO and performance. Wilburn Green, Toms [47] identified the positive mediation relationship of GSCM practice between MO and sustainable firm performance. The link between GEO, GSCM approach, and firm performance has not been tested before. Thus, our proposed hypothesis follows:

Hypothesis H10a. GSCM practices positively mediate the relation between GEO and economic performance.

Hypothesis H10b. GSCM practices positively mediate the relation between GEO and environmental performance.

\subsubsection{Control Variable}

To exaggerate the robustness and reliability of the study, the industries consider three control variables. These are possession of industry type, firm size, and firm age.

As a textile supply chain composed of industries from yarn manufacturing to garments manufacturing, all industries were not responsible for the same environmental effect. For example, the dyeing industry creates more hazardous and toxic effluent to the environment than other sectors.

As widely reflected in the literature, firm size is positive on GSCM practices and sustainability performance. Large firms can assemble resources to implement GSCM practices. The age of a firm may also influence performance as a result of GSCM adoption. An older firm is likely to build up resources and capabilities. One such support is the natural resource developed through the implementation of GSCM practice. 


\section{Research Methodology}

\subsection{Variable Measurement and Questionnaire Design}

For data collection, we use a questionnaire survey method, a much popular method in business research, by setting structuring questions for data collection and then using them to analyze by software to determine the inferential relationship among the variables. To provide the respondent with a level of intensity and feeling expressed without confusion, a 5-point Likert scale was used for the questionnaire. The measurement items of all the construct's sizes range from 1-“strongly agree" to 5-"strongly disagree". For green entrepreneurial orientation, dimensions (5-items) were adopted from [17]. Five items of market orientation are selected [49]. Five items of KMO are taken from [71]. Three dimensions of GSCM practices (9-items) were taken from [29], including internal environmental management, Eco-design, and cooperation with customers. Sustainable firm performance dimensions, mainly economic and environmental performance, are measures from [76]. For details of variables, measurement items are presented in Table 2.

\subsection{Sample and Data Collection}

The population of this study is the textile manufacturing industry in Bangladesh. Bangladesh has been positioned as the second-largest textile and apparel product exporter in the world and emerging developing economic participants in Asia. There are 425 yarn manufacturing industries, 796 fabric manufacturing, 240 wet processing industries, and 4560 manufacturing industries in Bangladesh [23]. The sample responded to this study in the currently employed owners and managers of the textile manufacturing firm of Bangladesh. In this study, a random sampling technique is adopted, as it has an equal chance for all the respondents. We collected data from 500 textile manufacturing industries. In this survey, we have seen that ten categories of factories were participants. Table 1 shows that most of the respondents are well experienced and doing jobs in different departments of the textile firm.

\subsection{Data Analysis Procedure}

This study used PLS-SEM because PLS-SEM is heavily used in social sciences, marketing, MIS, business strategy research [77]. The PLS structural equation modeling technique was used as a popularly accepted model to justify the theory with observational data (Hair et al., 2014). We analyze the data by smart, PLS 3.2.8 software. PLS offers a valuable tool for GSCM research owing to the high grade of flexibility it provides for the relationship between theory and data [36], which appears directly necessary given the present state of research in green supply chain management.

\subsection{Common Method Bias}

The problem of method bias is the primary source of measurement error, leading to an improper relationship among measurement items. Regarding its origins, the systematic error variance can severely impact the research findings, which may lead to inaccurate results. Hence, it is necessary to find out the causes of common method bias (CMB). We tested the CMB in two ways. First, we performed Harman's one-factor test to observe the principal axis factor analysis (PAF) [78]. After completing the test, we have found the total variance of a single construct is $34.897 \%$, which is a lower value than the recommended 50\% [79]. Second, we measure the CMB in variance inflation factors (VIF) benefits from the full collinearity test of the constructs, which also found a lower value than the recommended 3.3 [80]. Thus, CMB was not found in this study. 
Table 1. Demographic profile of the sample.

\begin{tabular}{|c|c|c|c|c|c|}
\hline & $\mathbf{N}$ & $(\%)$ & & $\mathbf{N}$ & $(\%)$ \\
\hline 1. Education & & & Washing & 7 & 2.6 \\
\hline Undergraduate & 33 & 12.4 & Home textile & 3 & 1.1 \\
\hline Graduate & 156 & 58.6 & Sweater & 8 & 3.0 \\
\hline Postgraduate & 75 & 28.2 & Accessories & 6 & 2.3 \\
\hline Doctorate & 2 & 0.8 & Textile chemical & 4 & 1.5 \\
\hline 2. Experience in Years & & & 5. Department & & \\
\hline$<5$ & 39 & 14.7 & Manufacturing & 93 & 35.0 \\
\hline $5.1-10$ & 53 & 19.9 & Supply chain & 104 & 39.1 \\
\hline $10.1-15$ & 142 & 53.4 & Marketing & 30 & 11.3 \\
\hline $15.1-20$ & 30 & 11.3 & Operations & 31 & 11.7 \\
\hline$>20$ & 2 & 0.8 & R\&D & 8 & 3.0 \\
\hline 3. Work Position & & & 6. Company Age & & \\
\hline Production officer & 83 & 31.2 & $<5$ & 29 & 10.9 \\
\hline Senior production officer & 28 & 10.2 & $5.1-10$ & 43 & 16.2 \\
\hline Asst. manager/manager & 97 & 36.5 & 10.1-15 & 58 & 21.8 \\
\hline GM/senior manager & 14 & 5.3 & $15.1-20$ & 39 & 14.7 \\
\hline $\mathrm{MD} /$ Director/CEO & 13 & 4.9 & $>20$ & 97 & 36.5 \\
\hline 4. Type of Industry & & & 7. Number of En & & \\
\hline Spinning & 10 & 3.8 & $<200$ & 51 & 19.2 \\
\hline Fabric & 33 & 12.4 & $201-500$ & 28 & 10.5 \\
\hline Apparel & 102 & 38.3 & 501-1000 & 32 & 12.0 \\
\hline Dyeing & 86 & 32.3 & $1001-2000$ & 39 & 14.7 \\
\hline Printing and packaging & 7 & 2.6 & $>2000$ & 116 & 43.6 \\
\hline
\end{tabular}

\subsection{Measurement Model}

We examine the construct reliability, convergent validity, and discriminant validity [77]. First, we determined to construct reliability by examining the composite reliability and Cronbach's alpha. From measurement in this study, all the composite reliability (CR) of the first-order constructs was between 0.863 and 0.948 (see Table 2). Cronbach's alpha (CA) values were found between 0.802 and 0.941 . The amount is higher than the recommended value of 0.7 , which signifies that the measurement model of our construct is reliable and fit for the model [81]. Second, convergent validity was assessed through the average variance extracted (AVE) [82]. All the construct AVE values were found within the range of 0.558 to 0.609 , which is above the threshold values of $>0.50$, indicating that this model's convergent validity is well accepted [77]. Discriminant validity confirms that the constructs are significantly different from one another. Discriminant validity was assessed through the Fornell-larger criterion, cross-loading, and HTMT. In this study, the square root of AVE as the diagonal elements is higher than the off-diagonal correlation in the rows and columns, signifying the fulfillment of the Fornell-Larcker criterion [82] (see Table 3). The cross-loading examination is evaluated by the outer loading of the measurement items on the associated construct greater than all other constructs' loadings. The results of the cross-loading matrix in our study found that the loading of all measurement items is higher on their intended construct (see Table 4). Finally, the Heterotrait-monotrait ratio (HTMT) of correlations was lower than 0.9 , indicating the satisfactory HTMT (see Table 5). Thus, the joint results of the Fornell-Larcker criterion, cross-loading matrix and HTMT confirm that the discriminant validity of the data is satisfied. 
Table 2. Measurement model-quality criteria.

\begin{tabular}{|c|c|c|c|c|c|}
\hline Item & Measurement Item of Construct & Loading & CA & CR & AVE \\
\hline \multicolumn{3}{|c|}{ Green Entrepreneurial Orientation (GEO) } & \multirow{6}{*}{0.831} & \multirow{6}{*}{0.881} & \multirow{6}{*}{0.597} \\
\hline GEO1 & $\begin{array}{l}\text { We have given priority to green practices, such as research and development, } \\
\text { product, and process innovation. }\end{array}$ & 0.804 & & & \\
\hline GEO2 & $\begin{array}{l}\text { In an uncertain environment, our firm adopts a proactive attitude to accept } \\
\text { provable green opportunities. }\end{array}$ & 0.785 & & & \\
\hline GEO3 & $\begin{array}{l}\text { Our firm typically takes a green initiative to respond to the } \\
\text { competitor's actions. }\end{array}$ & 0.732 & & & \\
\hline GEO4 & $\begin{array}{l}\text { Our firm always introduces green products, services, or technology first than } \\
\text { our competitors to become the leader of this sector. }\end{array}$ & 0.804 & & & \\
\hline GEO5 & To compete with our competitors, we adopt a competitive posture. & 0.735 & & & \\
\hline & Market Orientation (MO) & & & & \\
\hline MO1 & Our firm collects the customer's wants and needs better than our competitors. & 0.737 & \multirow{5}{*}{0.802} & \multirow{5}{*}{0.863} & \multirow{5}{*}{0.558} \\
\hline $\mathrm{MO} 2$ & We regularly and systematically collected our customers' information. & 0.736 & & & \\
\hline MO3 & $\begin{array}{l}\text { Customers' information is a critical tool for our organization to make } \\
\text { technological improvements. }\end{array}$ & 0.742 & & & \\
\hline $\mathrm{MO} 4$ & We regularly and systematically collected our competitors' information. & 0.741 & & & \\
\hline MO5 & $\begin{array}{l}\text { The sales and marketing department give more effort to exchange information } \\
\text { on strategies of competitors. }\end{array}$ & 0.778 & & & \\
\hline \multicolumn{3}{|c|}{ Knowledge Management Orientation (KMO) } & \multirow{6}{*}{0.839} & \multirow{6}{*}{0.886} & \multirow{6}{*}{0.609} \\
\hline KMO1 & We have clear rules for categorizing product knowledge. & 0.784 & & & \\
\hline KMO2 & We have clear rules for categorizing process knowledge. & 0.790 & & & \\
\hline KMO3 & Employees of our organization always use technology to cooperate. & 0.797 & & & \\
\hline KMO4 & $\begin{array}{l}\text { Our organization inspires us to exchange knowledge across } \\
\text { functional boundaries. }\end{array}$ & 0.804 & & & \\
\hline KMO5 & $\begin{array}{l}\text { Our organization has the opportunity to communicate with its judgment also } \\
\text { other departments. }\end{array}$ & 0.715 & & & \\
\hline \multicolumn{6}{|c|}{ Green Supply Chain Management Practice (GSCM) } \\
\hline \multicolumn{6}{|c|}{ Internal Environmental Management (IEM) } \\
\hline IEM1 & Top-level managers of our firm emphasize GSCM. & 0.728 & \multirow{11}{*}{0.941} & \multirow{11}{*}{0.948} & \multirow{11}{*}{0.549} \\
\hline IEM2 & $\begin{array}{l}\text { Mid-level managers are always supporting to establish the GSCM goal } \\
\text { of the organization. }\end{array}$ & 0.709 & & & \\
\hline IEM3 & Our firm support has an environmental management system. & 0.750 & & & \\
\hline \multicolumn{3}{|c|}{ Eco-Design } & & & \\
\hline ED1 & $\begin{array}{l}\text { Our firm strictly maintain the product design to reduce the consumption of } \\
\text { material/energy. }\end{array}$ & 0.721 & & & \\
\hline ED2 & $\begin{array}{l}\text { Our firm maintains the product design to reuse, recycle, } \\
\text { recovery material, parts. }\end{array}$ & 0.744 & & & \\
\hline ED3 & $\begin{array}{l}\text { Our firm maintains the product design to avoid or reduce the use of } \\
\text { hazardous products and their manufacturing process. }\end{array}$ & 0.731 & & & \\
\hline \multicolumn{3}{|c|}{ Cooperation with Customer (CC) } & & & \\
\hline CC1 & Our firm always support with customers for eco-design & 0.716 & & & \\
\hline $\mathrm{CC} 2$ & Our firm always supports customers for cleaner production. & 0.756 & & & \\
\hline CC3 & Our firm always supports customers for green packaging. & 0.752 & & & \\
\hline
\end{tabular}


Table 2. Cont

\begin{tabular}{|c|c|c|c|c|c|}
\hline Item & Measurement Item of Construct & Loading & CA & CR & AVE \\
\hline \multicolumn{6}{|c|}{ Sustainable Firm Performance (SFP) } \\
\hline \multicolumn{6}{|c|}{ Economic Performance (ECP) } \\
\hline ECP1 & $\begin{array}{l}\text { In comparison to the last three years now, the cost for materials } \\
\text { purchased is reduced. }\end{array}$ & 0.731 & \multirow{5}{*}{0.812} & \multirow{5}{*}{0.869} & \multirow{5}{*}{0.570} \\
\hline $\mathrm{ECP} 2$ & $\begin{array}{l}\text { In comparison to the last three years now cost for energy } \\
\text { consumption is decreased. }\end{array}$ & 0.740 & & & \\
\hline ECP3 & $\begin{array}{l}\text { In comparison to the last three years now, the fee for waste } \\
\text { discharge is decreased. }\end{array}$ & 0.815 & & & \\
\hline ECP4 & $\begin{array}{c}\text { In comparison to the last three years now, the return on } \\
\text { investment is improved. }\end{array}$ & 0.776 & & & \\
\hline ECP5 & In comparison to the last three years now, earnings per share are improved. & 0.708 & & & \\
\hline \multicolumn{6}{|c|}{ Environmental Performance (ENP) } \\
\hline ENP1 & In comparison to the last three years now, the air emission is reduced. & 0.763 & \multirow{5}{*}{0.831} & \multirow{5}{*}{0.881} & \multirow{5}{*}{0.597} \\
\hline ENP2 & $\begin{array}{l}\text { In comparison to the last three years now, the waste (water and concrete) } \\
\text { is reduced. }\end{array}$ & 0.719 & & & \\
\hline ENP3 & $\begin{array}{l}\text { In comparison to the last three years now, the consumption of hazardous/ } \\
\text { harmful/ toxic materials is decreased. }\end{array}$ & 0.838 & & & \\
\hline ENP4 & $\begin{array}{l}\text { In comparison to the last three years now, the frequency of environmental } \\
\text { accidents decreased. }\end{array}$ & 0.804 & & & \\
\hline ENP5 & $\begin{array}{l}\text { Our firm increase in energy saved due to conservation and } \\
\text { efficiency improvement. }\end{array}$ & 0.733 & & & \\
\hline
\end{tabular}

Table 3. Latent variable descriptive, correlations, and discriminant validity.

\begin{tabular}{lcccccccc}
\hline & Mean & SD & ECP & ENP & GEO & GSCM & KMO & MO \\
\hline ECP & 3.836 & 0.951 & 0.755 & & & & & \\
\hline ENP & 3.865 & 0.945 & 0.481 & 0.773 & & & & \\
\hline GEO & 3.652 & 1.083 & 0.502 & 0.618 & 0.773 & & & \\
\hline GSCM & 3.774 & 0.938 & 0.524 & 0.566 & 0.637 & 0.741 & & \\
\hline KMO & 3.887 & 0.932 & 0.563 & 0.507 & 0.503 & 0.531 & 0.780 & \\
\hline MO & 3.893 & 0.942 & 0.469 & 0.469 & 0.538 & 0.592 & 0.634 & 0.747 \\
\hline
\end{tabular}

Note-the diagonal (in italic) data represents the square root of the average variance extracted (AVE) of the construct. 
Table 4. Item cross-loading matrix of the constructs.

\begin{tabular}{|c|c|c|c|c|c|c|}
\hline & GEO & MO & KMO & GSCM & ECP & ENP \\
\hline GEO1 & 0.804 & 0.383 & 0.419 & 0.493 & 0.387 & 0.536 \\
\hline GEO2 & 0.785 & 0.437 & 0.425 & 0.515 & 0.366 & 0.478 \\
\hline GEO3 & 0.732 & 0.350 & 0.308 & 0.450 & 0.329 & 0.443 \\
\hline GEO4 & 0.804 & 0.447 & 0.372 & 0.498 & 0.439 & 0.496 \\
\hline GEO5 & 0.735 & 0.474 & 0.408 & 0.494 & 0.411 & 0.432 \\
\hline MO1 & 0.410 & 0.737 & 0.433 & 0.448 & 0.427 & 0.338 \\
\hline MO2 & 0.415 & 0.736 & 0.517 & 0.451 & 0.352 & 0.365 \\
\hline MO3 & 0.406 & 0.742 & 0.418 & 0.427 & 0.380 & 0.376 \\
\hline MO4 & 0.382 & 0.741 & 0.448 & 0.424 & 0.348 & 0.355 \\
\hline MO5 & 0.388 & 0.778 & 0.575 & 0.398 & 0.414 & 0.341 \\
\hline KM1 & 0.346 & 0.505 & 0.784 & 0.391 & 0.390 & 0.365 \\
\hline KM2 & 0.454 & 0.494 & 0.790 & 0.444 & 0.362 & 0.393 \\
\hline KM3 & 0.412 & 0.526 & 0.797 & 0.404 & 0.502 & 0.458 \\
\hline KM4 & 0.342 & 0.403 & 0.804 & 0.434 & 0.442 & 0.386 \\
\hline KM5 & 0.369 & 0.536 & 0.715 & 0.435 & 0.477 & 0.409 \\
\hline IEM1 & 0.544 & 0.432 & 0.383 & 0.728 & 0.468 & 0.455 \\
\hline IEM2 & 0.498 & 0.404 & 0.409 & 0.709 & 0.440 & 0.416 \\
\hline IEM3 & 0.538 & 0.467 & 0.458 & 0.750 & 0.466 & 0.494 \\
\hline ED1 & 0.453 & 0.502 & 0.384 & 0.721 & 0.405 & 0.420 \\
\hline ED2 & 0.460 & 0.468 & 0.428 & 0.744 & 0.375 & 0.422 \\
\hline ED3 & 0.528 & 0.500 & 0.419 & 0.731 & 0.358 & 0.469 \\
\hline CC1 & 0.391 & 0.410 & 0.348 & 0.716 & 0.354 & 0.330 \\
\hline CC2 & 0.449 & 0.358 & 0.392 & 0.756 & 0.333 & 0.380 \\
\hline CC3 & 0.471 & 0.429 & 0.359 & 0.752 & 0.294 & 0.400 \\
\hline ECP1 & 0.367 & 0.441 & 0.396 & 0.441 & 0.731 & 0.398 \\
\hline ECP2 & 0.329 & 0.423 & 0.446 & 0.390 & 0.740 & 0.348 \\
\hline ECP3 & 0.458 & 0.446 & 0.473 & 0.441 & 0.815 & 0.397 \\
\hline ECP4 & 0.423 & 0.386 & 0.413 & 0.366 & 0.776 & 0.355 \\
\hline ECP5 & 0.302 & 0.324 & 0.399 & 0.307 & 0.708 & 0.299 \\
\hline ENP1 & 0.541 & 0.340 & 0.357 & 0.451 & 0.366 & 0.763 \\
\hline ENP2 & 0.366 & 0.360 & 0.389 & 0.374 & 0.331 & 0.719 \\
\hline ENP3 & 0.512 & 0.406 & 0.446 & 0.499 & 0.359 & 0.838 \\
\hline ENP4 & 0.532 & 0.385 & 0.430 & 0.469 & 0.460 & 0.804 \\
\hline ENP5 & 0.410 & 0.322 & 0.344 & 0.372 & 0.333 & 0.733 \\
\hline
\end{tabular}

Note: Outer loading of the measurement items on the associated construct (black background) greater than all other constructs' loadings.

Table 5. Heterotrait-monotrait ratio (HTMT).

\begin{tabular}{lllllll}
\hline & ECP & ENP & GEO & GSCM & KMO & MO \\
\hline ECP & & & & & \\
\hline ENP & 0.577 & & & & \\
\hline GEO & 0.603 & 0.735 & & & \\
\hline GSCM & 0.584 & 0.629 & 0.713 & & \\
\hline KMO & 0.683 & 0.603 & 0.595 & 0.591 & \\
\hline MO & 0.647 & 0.575 & 0.655 & 0.663 & 0.774 \\
\hline
\end{tabular}

\section{Result and Findings}

\subsection{Structural Model and Hypothesis Testing}

In line with research objectives, the structured model (e.g., the hypothetical model) is developed to analyze the relationships of constructs variables. We tested the hypothesis from two-step contexts, including the significance of direct path analysis with set variables where 5000 bootstrapping samples were used to determine the path coefficient significance. 
Then, mediation effects were analyzed that of GSCM practice between GEO and firm performance and the mediation effect of MO and KMO in between GEO and GSCM practices, respectively. To measure the structural model's explanatory power, the $\mathrm{R}^{2}$ value was used as the dependent variable. The structural model accounted for $27.5 \%$ of the variance in economic performance, $32.1 \%$ of the environmental performance variance, which confirms the predictive validity (Hair et al., 2016). The study tests the association between the independent and dependent variables by path coefficient $(\beta)$ and $\mathrm{t}$-statistics. According to Table 6, there is direct and positive significant relationship of GEO on MO $(\mathrm{t}=12.883, \beta=0.538, p<0.001)$, GSCM practices $(\mathrm{t}=7.747, \beta=0.415, p<0.001)$, and KMO $(\mathrm{t}=10.799, \beta=0.503, p<0.001)$ successively. Therefore, $\mathrm{H} 1, \mathrm{H} 2$, and $\mathrm{H} 3$ are supported. Similarly, MO has a positive relationship on GSCM $(t=3.900, \beta=0.274, p<0.001)$. Thus, hypothesis $\mathrm{H} 3$ is accepted. Thus, the firm with greater GEO, MO capability will significantly be associated with GSCM practices. However, KMO has no significant relationship on $\operatorname{GSCM}(t=1.891, \beta=0.149, p<0.059)$. Thus, hypothesis H3 is not supported. Further, GSCM has found direct positive relationships with economic, ECP $(t=9.406, \beta=0.525$, $p<0.001)$ and environmental, ENP $(t=11.681, \beta=0.545, p<0.001)$. Therefore, H6 and $\mathrm{H} 7$ are supported. Finally, the impacts of three control variables (i.e., industry type, number of employees-Firm size, year of experience-Firm age) in explaining performance variation were found to be statistically insignificant $(p>0.05)$ except industry type with environmental performance must be found statistically significant. The reason is different industries have different amounts of pollution creation and impact on the environment.

Table 6. Bootstrapping results for structural model evaluation.

\begin{tabular}{|c|c|c|c|c|c|}
\hline Hypothesis & Path & Path Coefficient & T Statistics & $p$ Values & Decision \\
\hline $\mathrm{H} 1$ & $\mathrm{GEO} \rightarrow \mathrm{MO}$ & 0.538 & 12.883 & $0.000 * *$ & Supported \\
\hline $\mathrm{H} 2$ & $\mathrm{GEO} \rightarrow \mathrm{GSCM}$ & 0.415 & 7.747 & $0.000 * *$ & Supported \\
\hline H3 & $\mathrm{GEO} \rightarrow \mathrm{KMO}$ & 0.503 & 10.799 & 0.000 ** & Supported \\
\hline $\mathrm{H} 4$ & $\mathrm{MO} \rightarrow \mathrm{GSCM}$ & 0.274 & 3.900 & $0.000 * *$ & Supported \\
\hline H5 & $\mathrm{KMO} \rightarrow \mathrm{GSCM}$ & 0.149 & 1.891 & 0.059 & Not supported \\
\hline H6 & $\mathrm{GSCM} \rightarrow \mathrm{ECP}$ & 0.525 & 9.406 & $0.000 * *$ & Supported \\
\hline $\mathrm{H7}$ & $\mathrm{GSCM} \rightarrow \mathrm{ENP}$ & 0.545 & 11.681 & $0.000 * *$ & Supported \\
\hline \multirow{6}{*}{ Control variable } & Industry type $\rightarrow$ ECP & 0.031 & 0.656 & 0.512 & Insignificant \\
\hline & Industry type $\rightarrow$ ENP & 0.135 & 2.751 & 0.004 & Significant \\
\hline & Firm age $\rightarrow$ ECP & -0.035 & 0.624 & 0.532 & Insignificant \\
\hline & Firm age $\rightarrow$ ENP & 0.014 & 0.255 & 0.799 & Insignificant \\
\hline & Firm size $\rightarrow$ ECP & 0.000 & 0.003 & 0.998 & Insignificant \\
\hline & Firm size $\rightarrow$ ENP & 0.071 & 1.396 & 0.163 & Insignificant \\
\hline
\end{tabular}

\subsection{Test for Mediation Effect}

In line with [83] guidelines, we tested the mediating effect of GSCM practices and market orientation. Path coefficient direct path of the independent and mediating variable (i.e., iv-mv) and mediating and dependent variable (i.e., IV-DV) is used for negotiating effect analysis [84]. From the path coefficients of the bootstrapping, the results found the signaling effect's significance has been calculated based on (Hair et al. 2014). Further, the variance accounted for (V.A.F.) has been estimated to determine the mediating effects' size. The results of the mediating effect are shown in Table 7 . The results indicate that there is a significant indirect effect of GEO on GSCM practices through the mediation of MO $(\mathrm{t}=4.073, \beta=0.189, p<0.001)$ and $\mathrm{KMO}(\mathrm{t}=2.835 \beta=0.154, p<0.001)$. These findings support the hypothesis of $\mathrm{H} 8$ and $\mathrm{H} 9$. Thus, results illustrate that $\mathrm{MO}$ and $\mathrm{KMO}$ partially 
mediate the relation between GEO and GSCM practices. Similarly, GEO has a significant indirect effect on economic and environmental performance through the mediation of GSCM practices $(t=2.805, \beta=0.232, p<0.001)$ and $(t=2.045, \beta=0.154, p<0.001)$. This finding supports H10a and $\mathrm{H} 10 \mathrm{~b}$. This result demonstrates that GSCM practices partially mediate the relationship between GEO and economic and environmental performance.

Table 7. Summary of mediation results.

\begin{tabular}{|c|c|c|c|c|c|c|c|c|c|}
\hline & Indirect Path & & & & & & & & \\
\hline Hypothesis & Path & $\beta$ & Path & $\beta$ & Mediation Effect $\beta$ & t-Value & Total Effect & VAF & Decision \\
\hline H8 & $\mathrm{GEO} \rightarrow \mathrm{MO}$ & 0.538 & $\mathrm{MO} \rightarrow \mathrm{GSCM}$ & 0.351 & 0.189 & $4.073 *$ & 0.638 & 0.296 & Partial \\
\hline H9 & $\mathrm{GEO} \rightarrow \mathrm{KMO}$ & 0.600 & $\mathrm{KMO} \rightarrow \mathrm{GSCM}$ & 0.257 & 0.154 & $2.835 *$ & 0.720 & 0.214 & Partial \\
\hline H10a & $\mathrm{GEO} \rightarrow \mathrm{GSCM}$ & 0.720 & $\mathrm{GSCM} \rightarrow \mathrm{ECP}$ & 0.323 & 0.232 & $2.805 *$ & 0.610 & 0.380 & Partial \\
\hline $\mathrm{H} 10 \mathrm{~b}$ & $\mathrm{GEO} \rightarrow \mathrm{GSCM}$ & 0.718 & $\mathrm{GSCM} \rightarrow \mathrm{ENP}$ & 0.215 & 0.154 & $2.045^{*}$ & 0.741 & 0.207 & Partial \\
\hline
\end{tabular}

Notes: bootstrapping $(\mathrm{n}=5000) .{ }^{*} p<0.001$.

\section{Discussion and Implication}

\subsection{Discussions}

Drawing upon DCV and RA-T, and RVB, this study develops a hypothetical model and assesses the relationship of strategic orientation such as GEO, MO, KMO and then analyzes them in terms of GSCM practice and sustainable textiles firm performance. The results reveal that the GEO posited with GSCM practices relationship is significantly supported. Prior studies on GSCM practices have focused on different institutional pressure, recognizing the fundamental elements and the effect [10]. Therefore, a lack of research to identify the firm-level antecedents of GSCM practice is fulfilled by empirically validated findings, i.e., green entrepreneurial orientations stance as an essential organizational antecedent to adopt GSCM practices.

The study reveals a significant relationship between MO with GSCM practices adoption. Consistent with Jiang, Chai's [17] findings, it confirms that market knowledge is the facilitator of entrepreneurial activities such as new ideas, green innovation, which bring competitive advantages.

The results do not support KMO's relationship with GSCM practices. The findings seem surprising since prior studies found a positive connection with innovation performance [75]. In reality, the entrepreneurs in Bangladesh textile firms are more concerned with high productivity than knowledge management, acquisition, sharing, and transformation. Moreover, the textile and R.M.G. industry is a labor-intensive industry where internal organizational management prioritizes knowledge buildup.

Though the KMO does not have a direct positive relationship with GSCM practices adoption, a significant indirect mediation effect can be said that KMO influences to motivate the GEO to adopt GSCM practices in the firm. Further, the study explored the positive mediation effect of market orientation (MO) in the relationship between green entrepreneurial orientation and GSCM practices. Consistent with Jiang, Chai's [17] study, our hypothesis has significantly supported the mediation relationship of MO between GEO and GSCM practices. Finally, the study proved that GSCM practices also partially mediate the relationship between GEO and sustainable firm performance.

This study has hypothesized that the adoption and implementation of GSCM practices bring a significant impact on company performance, e.g., economic and environment. Consistent with studies by [11] and [12], our results proved this hypothesis.

\subsection{Theoretical Implication}

This study contributes to the strategic orientation and GSCM literature in several ways. It helps academics and researchers to further comprehensively investigate and adopt a broader context of GSCM practices with strategic direction both in theory and techniques. First, drawing upon dynamic capabilities, firm sensing capability identifies 
the eco-friendly customer demand. Hence GEO seizing capability mobilizes and leverages the firm resources in green operations, and transforming capability renews the traditional system to adopt modern competitive strategies. Thus, this study illustrates that GEO and dynamic capability are intertwined with each other in three functional processes: inherent spirit to initiate and develop green innovation, proactive attitude to capture new opportunities, and risk-taking behavior to adopt GSCM practices.

Second, this study extends the GSCM literature by discovering the firm-level antecedents of GSCM practices at first. The previous research emphasized either fundamental direct effect analysis [12] or institutional pressure for GSCM practice adoption [85] or investigated the need and components of GSCM practices.

Third, prior research notes that GEO alone not sufficient to carry out superior firm performance unless a mediation effect, given that there exists a missing linkage with organization performance. The study result contributes to the literature by identifying the mediation role of GSCM practices between green entrepreneurial orientation (GEO) and sustainable firm performance.

Fourthly, the resource advantage theory and market orientation ornamented this study by monitoring and analyzing the customer and competitor strategy, initiating, and applying GSCM practices to meet the eco-friendly customer requirement. According to the resourcebased view, the knowledge management orientation of firms empowered the organization by acquiring the internal and external environmental knowledge and rebuilding to achieve competitive advantages.

Finally, this study enlightens the theoretical research on how managers' interplay with strategic capabilities related to GSCM practices in a competitive, dynamic, and complex environment. Overall, the key contributions of this study to current literature offer opportunities to identify the interplay among strategic orientation, GSCM practices, and sustainable firm performance.

\subsection{Managerial Implication}

First, this study helps the textiles industry practitioners to trace and understand the strategic orientation and GSCM practice implementation strategies in the operations and accordingly reset environmental resources to grab strategic opportunities, identify priorities towards superior firm performances.

Second, the business growth and value creation of the organization depends on the strategic orientation of the entrepreneur. GEO firms adopt GSCM practices to capture possible market opportunities and meet the eco-friendly customer requirement. Dynamic capabilities of GEO firms enhance the strategies and decision-making ability of the entrepreneur by adopting GSCM practices to gain a specific sustainable goal.

Third, entrepreneurs and managers who are struggling for greater efficiency and effectiveness may apply the findings in business strategies towards an eco-friendly, successful, and profit-seeking firm through capturing competitive advantages. The practitioners of the Bangladesh textiles industry may get a comprehensive understanding of the interplay of strategic orientation and contextual factors to implement GSCM practices that reduce environmental impact and improve firm economic performance considering both internal and external pressure.

Fourthly, findings will help the textiles and R.M.G. practitioners to capture the implementation strategies of GSCM practices and consistency gaps, and inherent change structure, its production, and product system, its culture accordingly towards the more excellent sustainable firm performance.

Finally, the findings may facilitate the textile manufacturing industry in developing countries (e.g., Bangladesh, India, Ghana, Srilanka) to improve their GSCM practices while mitigating the environmental impact. The results can be tested and extended for other manufacturing industry contexts (e.g., food, leather, chemicals, plastics, electronics, etc.), including developing countries with similar contexts, cultures, and markets to improve firm performance. 


\section{Conclusions and Future Research Directions}

\subsection{Conclusions}

This study illustrates the effect of strategic orientation on the implementation of GSCM practices in the textile manufacturing firms and further tests the sustainability performance from economic and environmental contexts. It follows the DCV, RA-T, and RBV theory to examine the performance outcomes of green entrepreneurial orientation, market orientation, and knowledge management orientation to implement GSCM practices. This study provides empirical evidence to account for the influence of strategic orientation on the successful adoption and implementation of the GSCM approach and, subsequently, positive effects on economic and environmental performance. GSCM practices are the best way for the firm to minimize the adverse impact of their activities on the environment, and GEO firms only can reduce this negative impact through GSCM practices. Hence GEO and GSCM have become valuable research topics nowadays. In this study, the result indicates that the GEO firm has spirit, inspiration, and culture of innovative initiatives, proactive posture in their activities, and risk-taking behavior to undertake new challenges to make the ecological society through GSCM practices. The study result found a positive relationship between GEO on GSCM practice. Similarly, GSCM courses also found a positive connection with sustainable firm performance. Furthermore, the output indicates that market orientation accelerates the GEO performance activities towards GSCM practices implementation. Finally, this study provides a unique contribution to the GEO, GSCM literature, and guidelines for entrepreneurs and managers for developing an ecologically sustainable society and prove them a legitimate organization. This study provides managerial insights into the necessity of strategic orientation and GSCM practice adoption for achieving competitive advantages. It lays the foundation for the manager, practitioner, and environmental management research to highlight the importance of GSCM practice to improve sustainability in operations.

\subsection{Limitations and Future Research Direction}

This study has some limitations. First, the research was conducted only on a single textiles manufacturing sector of a country. The data were collected from a single respondent per firm (e.g., either top or middle management), limiting the study's generalizability. Second, more comprehensive data collection from the supply chain focal firms, including the multiple upstream and downstream stakeholders, may provide different research insights. Third, this study explores the direct and mediating effects. Future research may focus on the mediator in strategic orientation and GSCM relationship, and also on the mediator in GSCM practice and sustainable firm performance on a broader scale, including multiple business stakeholders of the textile industry. How firms can strategically position themselves to take advantage of risks or disruption (e.g., scarce natural resources) in the dynamic environment could be an exciting research avenue.

Author Contributions: Conceptualization, M.A.H. and Y.B.; methodology, M.A.H. and M.D.; software, M.A.H. and A.A.A.; validation, N.N. and M.I.; formal analysis, M.A.H., M.I., N.N and M.D.; investigation, A.A.A.; resources, M.D. and M.I.; data curation, N.N and M.D.; writing-original draft preparation, M.A.H.; writing-review and editing, M.A.H., Y.B. and M.I.; visualization, A.A.A. and M.I.; supervision, Y.B.; project administration, M.A.H and Y.B.; funding acquisition, M.A.H and Y.B. All authors have read and agreed to the published version of the manuscript.

Funding: Authors received no external funding for this project.

Data Availability Statement: The data used to support the findings of this study are available from the corresponding author upon request.

Acknowledgments: Habib is grateful for the financial assistance received from the Chinese Scholarship Council for his Ph.D. at Huazhong University of Science and Technology, Wuhan, China.

Conflicts of Interest: The authors declare no conflict of interest. 


\section{References}

1. Koberg, E.; Longoni, A. A Systematic Review of Sustainable Supply Chain Management in Global Supply Chains. J. Clean. Prod. 2019, 207, 1084-1098. [CrossRef]

2. WCED. Our Common Future; Oxford University Press: Oxford, UK, 1987.

3. EPA. Environment Protection Agency. What is Sustainability? Available online: https://www.epa.gov/sustainability/learnabout-sustainability (accessed on 15 October 2019).

4. Lin, Y.; Luo, J.; Ieromonachou, P.; Rong, K.; Huang, L. Strategic Orientation of Servitization in Manufacturing Firms and Their Impacts on Firm Performance. Ind. Manag. Data Syst. 2019, 119, 292-316. [CrossRef]

5. Niinimäki, K.; Peters, G.; Dahlbo, H.; Perry, P.; Rissanen, T.; Gwilt, A. The Environmental Price of Fast Fashion. Nat. Rev. Earth Environ. 2020, 1, 189-200. [CrossRef]

6. Sahi, G.K.; Gupta, M.C.; Cheng, T. The Effects of Strategic Orientation on Operational Ambidexterity: A Study of Indian S.M.E.s in the Industry 4.0 Era. Int. J. Prod. Econ. 2019, 220, 107395. [CrossRef]

7. Covin, J.G.; Slevin, D.P.; Schultz, R.L. Implementing Strategic Missions: Effective Strategic, Structural, and Tactical Choices. J. Manag. Stud. 1994, 31, 481-506. [CrossRef]

8. Evers, N.; Gliga, G.; Rialp-Criado, A. Strategic Orientation Pathways in International New Ventures and Born Global FirmsTowards a Research Agenda. J. Int. Entrep. 2019, 17, 287-304. [CrossRef]

9. Faisal, A.; Hermawan, A.; Arafah, W. The Influence of Strategic Orientation on Firm Performance Mediated by Social Media Orientation at MSMEs. Int. J. Sci. Eng. Inven. 2018, 4, 22-31. [CrossRef]

10. Zhu, Q.; Sarkis, J.; Geng, Y. Green Supply Chain Management in China: Pressures, Practices and Performance. Int. J. Oper. Prod. Manag. 2005, 25, 449-468. [CrossRef]

11. Eltayeb, T.K.; Zailani, S.; Ramayah, T. Green Supply Chain Initiatives among Certified Companies in Malaysia and Environmental Sustainability: Investigating the Outcomes. Resour. Conserv. Recycl. 2011, 55, 495-506. [CrossRef]

12. Foo, P.-Y.; Lee, V.-H.; Tan, G.W.-H.; Ooi, K.-B. A Gateway to Realizing Sustainability Performance via Green Supply Chain Management Practices: A PLS-ANN Approach. Expert Syst. Appl. 2018, 107, 1-14.

13. Wang, S.; Li, J.; Zhao, D. Institutional Pressures and Environmental Management Practices: The Moderating Effects of Environmental Commitment and Resource Availability. Bus. Strat. Environ. 2018, 27, 52-69. [CrossRef]

14. Zhu, Q.; Sarkis, J.; Lai, K. Institutional-based antecedents and performance outcomes of internal and external green supply chain management practices. J. Purch. Supply Manag. 2013, 19, 106-117. [CrossRef]

15. Luthra, S.; Garg, D.; Haleem, A. Critical Success Factors of Green Supply Chain Management for Achieving Sustainability in the Indian Automobile Industry. Prod. Plan. Control. 2015, 26, 339-362.

16. Gast, J.; Gundolf, K.; Cesinger, B. Doing Business in a Green Way: A Systematic Review of the Ecological Sustainability Entrepreneurship Literature and Future Research Directions. J. Clean. Prod. 2017, 147, 44-56. [CrossRef]

17. Jiang, W.; Chai, H.; Shao, J.; Feng, T. Green Entrepreneurial Orientation for Enhancing Firm Performance: A Dynamic Capability Perspective. J. Clean. Prod. 2018, 198, 1311-1323. [CrossRef]

18. Hughes, P.; Hodgkinson, I.R.; Hughes, M.; Arshad, D. Explaining the Entrepreneurial Orientation-Performance Relationship in Emerging Economies: The Intermediate Roles of Absorptive Capacity and Improvisation. Asia Pac. J. Manag. 2017, 35, 1025-1053. [CrossRef]

19. Habib, A.; Bao, Y.; Ilmudeen, A. The Impact of Green Entrepreneurial Orientation, Market Orientation and Green Supply Chain Management Practices on Sustainable Firm Performance. Cogent Bus. Manag. 2020, 7, 1743616. [CrossRef]

20. Islam, M.; Perry, P.; Gill, S. Mapping Environmentally Sustainable Practices in Textiles, Apparel and Fashion Industries: A Systematic Literature Review. J. Fash. Mark. Manag. Int. J. 2020. [CrossRef]

21. Todeschini, B.V.; Cortimiglia, M.N.; Callegaro-De-Menezes, D.; Ghezzi, A. Innovative and Sustainable Business Models in the Fashion Industry: Entrepreneurial Drivers, Opportunities, and Challenges. Bus. Horizons 2017, 60, 759-770. [CrossRef]

22. Yadlapalli, A.; Rahman, S.; Gunasekaran, A. Socially Responsible Governance Mechanisms for Manufacturing Firms in Apparel Supply Chains. Int. J. Prod. Econ. 2018, 196, 135-149. [CrossRef]

23. BGMEA. About the Garment Industry of Bangladesh. 2019. Available online: http://www.bgmea.com.bd/home/about/ AboutGarmentsIndustry (accessed on 7 March 2019).

24. Mahmud-ul-Islam, S. Approaching Sustainability in Textile and Garment Industries, Bangladesh. Master's Thesis, Royal Institute of Technology (KTH), Stockholm, Sweden, 2013.

25. Macchion, L.; Da Giau, A.; Caniato, F.; Caridi, M.; Danese, P.; Rinaldi, R.; Vinelli, A. Strategic Approaches to Sustainability in Fashion Supply Chain Management. Prod. Plan. Control. 2017, 29, 9-28. [CrossRef]

26. Huq, F.A.; Chowdhury, I.N.; Klassen, R.D. Social Management Capabilities of Multinational Buying Firms and Their Emerging Market Suppliers: An Exploratory Study of the Clothing Industry. J. Oper. Manag. 2016, 46, 19-37. [CrossRef]

27. Reza, A.K.; Islam, S.; Shimu, A.A. Green Industry in Bangladesh: An Overview. Environ. Manag. Sustain. Dev. 2017, 6. [CrossRef]

28. Chu, S.H.; Yang, H.; Lee, M.; Park, S. The Impact of Institutional Pressures on Green Supply Chain Management and Firm Performance: Top Management Roles and Social Capital. Sustainability 2017, 9, 764. [CrossRef]

29. Zhu, Q.; Sarkis, J.; Lai, K.-H. Green Supply Chain Management: Pressures, Practices and Performance within the Chinese Automobile Industry. J. Clean. Prod. 2007, 15, 1041-1052. [CrossRef] 
30. Saeed, A.; Jun, Y.; Nubuor, S.A.; Priyankara, H.P.R.; Jayasuriya, M.P.F. Institutional Pressures, Green Supply Chain Management Practices on Environmental and Economic Performance: A Two Theory View. Sustainability 2018, 10, 1517. [CrossRef]

31. Majumdar, A.; Sinha, S. Modeling the Barriers of Green Supply Chain Management in Small and Medium Enterprises. Manag. Environ. Qual. Int. J. 2018, 29, 1110-1122. [CrossRef]

32. Islam, S.; Tseng, M.; Karia, N.; Lee, C.-H. Assessing Green Supply Chain Practices in Bangladesh Using Fuzzy Importance and Performance Approach. Resour. Conserv. Recycl. 2018, 131, 134-145. [CrossRef]

33. Hart, S.L. A Natural-Resource-Based View of the Firm. Acad. Manag. Rev. 1995, 20, 986-1014.

34. Laosirihongthong, T.; Adebanjo, D.; Tan, K.C. Green Supply Chain Management Practices and Performance. Ind. Manag. Data Syst. 2013, 113, 1088-1109. [CrossRef]

35. Tippayawong, K.Y.; Niyomyat, N.; Sopadang, A.; Ramingwong, S. Factors Affecting Green Supply Chain Operational Performance of the Thai Auto Parts Industry. Sustainability 2016, 8, 1161. [CrossRef]

36. Vanalle, R.M.; Ganga, G.M.D.; Filho, M.G.; Lucato, W.C. Green Supply Chain Management: An Investigation of Pressures, Practices, and Performance within the Brazilian Automotive SUPPLY chain. J. Clean. Prod. 2017, 151, 250-259. [CrossRef]

37. Yu, W.; Ramanathan, R.; Wang, X.; Yang, J. Operations Capability, Productivity and Business Performance. Ind. Manag. Data Syst. 2018, 118, 126-143. [CrossRef]

38. Teece, D.J. Explicating Dynamic Capabilities: The Nature and Micro-Foundations of (Sustainable) Enterprise Performance. Strat. Manag. J. 2007, 28, 1319-1350.

39. Altinay, L.; Madanoglu, M.; De Vita, G.; Arasli, H.; Ekinci, Y. The Interface between Organizational Learning Capability, Entrepreneurial Orientation, and SME Growth. J. Small Bus. Manag. 2016, 54, 871-891. [CrossRef]

40. Chan, R.Y.; He, H.; Chan, H.K.; Wang, W.Y. Environmental Orientation and Corporate Performance: The Mediation Mechanism of Green Supply Chain Management and Moderating Effect of Competitive Intensity. Ind. Mark. Manag. 2012, 41, 621-630. [CrossRef]

41. Syrjä, P.; Puumalainen, K.; Sjögrén, H.; Soininen, J.; Durst, S. Entrepreneurial Orientation in Firms with a Social Mission-A Mixed-Methods Approach. Cogent Bus. Manag. 2019, 6, 6. [CrossRef]

42. Dean, T.J.; McMullen, J.S. Toward a Theory of Sustainable Entrepreneurship: Reducing Environmental Degradation Through Entrepreneurial Action. J. Bus. Ventur. 2007, 22, 50-76. [CrossRef]

43. Harvey, F. Start Me up. Green Futures 2007, 65, 18-25.

44. Forouharfar, A.; Rowshan, S.A.; Salarzehi, H. Social Entrepreneurship Strategic GRID: Visualizing Classification, Orientation and Dimensionality in the Strategic Paradigms of Governmental-Scale Social Entrepreneurship (A Literature-Based Approach). Cogent Bus. Manag. 2019, 6, 6. [CrossRef]

45. Pacheco, D.F.; Dean, T.J.; Payne, D.S. Escaping the Green Prison: Entrepreneurship and the Creation of Opportunities for Sustainable Development. J. Bus. Ventur. 2010, 25, 464-480. [CrossRef]

46. Thoeni, A.; Marshall, G.W.; Campbell, S.M. A Resource-Advantage Theory Typology of Strategic Segmentation. Eur. J. Mark. 2016, 50, 2192-2215. [CrossRef]

47. Green, K.W.; Toms, L.C.; Clark, J.H. Impact of Market Orientation on Environmental Sustainability Strategy. Manag. Res. Rev. 2015, 38, 217-238. [CrossRef]

48. Zahra, S.A. Being Entrepreneurial and Market Driven: Implications for Company Performance. J. Strat. Manag. 2008, 1, 125-142. [CrossRef]

49. Frambach, R.T.; Prabhu, J.; Verhallen, T.M. The Influence of Business Strategy on New Product Activity: The Role of Market Orientation. Int. J. Res. Mark. 2003, 20,377-397. [CrossRef]

50. Choi, D. Market Orientation and Green Supply Chain Management Implementation. Int. J. Adv. Logist. 2014, 3, 1-9. [CrossRef]

51. Bamfo, B.A.; Kraa, J.J. Market Orientation and Performance of Small and Medium Enterprises in Ghana: The Mediating Role of Innovation. Cogent Bus. Manag. 2019, 6, 6. [CrossRef]

52. Wernerfelt, B. A Resource-Based View of the Firm. Strat. Manag. J. 1984, 5, 171-180. [CrossRef]

53. Barney, J. Firm Resources and Sustained Competitive Advantage. J. Manag. 1991, 17, 99-120. [CrossRef]

54. Nelson, R.R. Why Do Firms Differ, and How Does It Matter? Strat. Manag. J. 1991, 12, 61-74. [CrossRef]

55. Powell, T.C. Competitive Advantage: Logical and Philosophical Considerations. Strat. Manag. J. 2001, 22, 875-888. [CrossRef]

56. Kraaijenbrink, J.; Spender, J.-C.; Groen, A.J. The Resource-Based View: A Review and Assessment of Its Critiques. J. Manag. 2010, 36, 349-372. [CrossRef]

57. Newbert, S.L. Empirical Research on the Resource-Based View of the Firm: An Assessment and Suggestions for Future Research. Strat. Manag. J. 2007, 28, 121-146. [CrossRef]

58. Bolisani, E.; Bratianu, C. Knowledge Strategy Planning: An Integrated Approach to Manage Uncertainty, Turbulence, and Dynamics. J. Knowl. Manag. 2017, 21, 233-253. [CrossRef]

59. Zaim, H.; Keceli, Y.; Jaradat, A.; Kastrati, S. The effects of Knowledge Management Processes on Human Resource Management. J. Sci. Technol. Policy Manag. 2018, 9, 310-328. [CrossRef]

60. Habib, A.; Bao, Y. Impact of Knowledge Management Capability and Green Supply Chain Management Practices on Firm Performance. Int. J. Res. Bus. Soc. Sci. 2019, 8, 240-255. [CrossRef]

61. Kyobe, M. A Knowledge Management Approach to Resolving the Crises in the Information Systems Discipline. J. Syst. Inf. Technol. 2010, 12, 161-173. [CrossRef] 
62. Rauch, A.; Wiklund, J.; Lumpkin, G.T.; Frese, M. Entrepreneurial Orientation and Business Performance: An Assessment of Past Research and Suggestions for the Future. Entrep. Theory Pract. 2009, 33, 761-787. [CrossRef]

63. Montiel-Campos, H. Entrepreneurial Orientation, and Market Orientation. Systematic Literature Review and Future Research. J. Res. Mark. Entrep. 2018, 20, 292-322.

64. Huang, J.-W.; Li, Y.-H. Green Innovation and Performance: The View of Organizational Capability and Social Reciprocity. J. Bus. Ethic 2015, 145, 309-324. [CrossRef]

65. Teece, D.J. Dynamic Capabilities, and Entrepreneurial Management in Large Organizations: Toward a Theory of the (Entrepreneurial). Eur. Econ. Rev. 2016, 86, 202-216. [CrossRef]

66. Ahuja, G.; Lampert, C.M. Entrepreneurship in the Large Corporation: A Longitudinal Study of How Established Firms Create Breakthrough Inventions. Strat. Manag. J. 2001, 22, 521-543. [CrossRef]

67. Agarwal, S.; Erramilli, M.K.; Dev, C.S. Market Orientation and Performance in Service Firms: Role of Innovation. J. Serv. Mark. 2003, 17, 68-82. [CrossRef]

68. Matear, S.; Osborne, P.; Garrett, T.; Gray, B.J. How Does Market Orientation Contribute to Service Firm Performance? An Examination of Alternative Mechanisms. Eur. J. Mark. 2002, 36, 1058-1075.

69. Rehman, M.A.A.; Shrivastava, R.L. An Innovative Approach to Evaluate Green Supply Chain Management (GSCM) Drivers by Using Interpretive Structural Modeling (I.S.M.). Int. J. Innov. Technol. Manag. 2011, 8, 315-336. [CrossRef]

70. Urban, B.; Govender, D.P. Empirical Evidence on Environmental Management Practices. Eng. Econ. 2012, 23, 209-215. [CrossRef]

71. Attia, A.; Eldin, I.E. Organizational Learning, Knowledge Management Capability and Supply Chain Management Practices in the Saudi Food Industry. J. Knowl. Manag. 2018, 22, 1217-1242. [CrossRef]

72. Bowen, F.; Cousins, P.; Lamming, R.; Faruk, A.C. Horses for Courses: Explaining the Gap Between the Theory and Practice of Green Supply. Greener Manag. Int. 2001, 35, 41-60.

73. Min, H.; Galle, W.P. Green Purchasing Practice of U.S. Firms. Int. J. Oper. Prod. Manag. 2001, 21, 1222-1238. [CrossRef]

74. Tseng, S.-M. The Impact of Knowledge Management Capabilities and Supplier Relationship Management on Corporate Performance. Int. J. Prod. Econ. 2014, 154, 39-47. [CrossRef]

75. Gharakhani, D.; Mousakhani, M. Knowledge Management Capabilities, and S.M.E.s' Organizational Performance. J. Chin. Entrep. 2012, 4, 35-49.

76. Paulraj, A. Understanding the Relationships between Internal Resources and Capabilities, Sustainable Supply Management, and Organizational Sustainability. J. Supply Chain Manag. 2011, 47, 19-37. [CrossRef]

77. Hair, J.F.; Hult, G.T.M.; Ringle, C.; Sarstedt, M. A Primer on Partial Least Squares Structural Equation Modeling (PLS-SEM); Sage Publications: Thousand Oaks, CA, USA, 2016.

78. Harman, H.H. Modern Factor Analysis; University of Chicago Press: Chicago, IL, USA, 1976.

79. Podsakoff, P.M.; MacKenzie, S.B.; Lee, J.-Y.; Podsakoff, N.P. Common Method Biases in Behavioral Research: A Critical Review of the Literature and Recommended Remedies. J. Appl. Psychol. 2003, 88, 879-903. [CrossRef] [PubMed]

80. Kock, N. Common Method Bias in PLS-SEM: A Full Collinearity Assessment approach. Int. J. eCollab. 2015, 11, 1-10. [CrossRef]

81. Hair, J.F., Jr.; Sarstedt, M.; Hopkins, L.; Kuppelweiser, V.G. Partial Least Squares Structural Equation Modeling (PLS-SEM) An Emerging Tool in Business Research. Eur. Bus. Rev. 2014, 26, 106-121.

82. Fornell, C.; Larcker, D.F. Structural Equation Models with Unobservable Variables and Measurement Error: Algebra and Statistics. J. Mark. Res. 1981, 18, 382-388. [CrossRef]

83. Preacher, K.J.; Hayes, A.F. Asymptotic and Resampling Strategies for Assessing and Comparing Indirect Effects in Multiple Mediator Models. Behav. Res. Methods 2008, 40, 879-891. [CrossRef]

84. Ilmudeen, A.; Bao, Y.; Alharbi, I.M. How Does Business-IT Strategic Alignment Dimension Impact on Organizational Performance Measures. J. Enterp. Inf. Manag. 2019, 32, 457-476. [CrossRef]

85. Wang, J.; Dai, J. Sustainable Supply Chain Management Practices and Performance. Ind. Manag. Data Syst. 2018, $118,2-21$. [CrossRef] 